from bluebird nest boxes on the Brandon line, to timber bridges at Tisdale, to the box serving as a seat in the lookout room on top of a fire tower near Glaslyn.

A search of the surrounding woods for the den tree has proven unsuccessful so far. We have tapped and knocked and pounded on literally dozens of trees with woodpecker holes in them with no results. But with an elusive species such as the "Fairy Diddle" (a popular name for all species of flying squirrels), some mystery must remain. The search for the den tree goes on. The rolled oats and peanuts continue to disappear every night.

\section{LYNX PREDATION}

HANS DE VOGEL, Box 219, Neilburg, Saskatchewan. SOM 2CO

I would like to tell you about an experience I had once. One year we decided to try and raise some ducks on our lake. Early in May we got thirtyone, day old White Peking ducklings, from the hatchery. We easily raised them in the barn under a heat lamp. When their feathers started to show we brought them to the lake, at first within a snow fence half in and half out of the water. They had a wooden feed trough and we fed them boiled braley mixed with chick starter. There were thirty then; one had gotten stepped on by a cow. After about ten days we took the snow fence away and let them go.

It was a beautiful sight to see, the white ducks spread all over the lake, until one morning they would not come for their feed. Instead they stayed in a tight bunch in the middle of the lake. I got my binoculars, stood on the hill and counted twenty-seven ducklings. The next morning the same thing and there were another four missing.
That same day after dinner, we heard crows and magpies giving alarm calls near the lake. I walked over and the same thing, a tight bunch of ducks in the middle of the lake. Only one thing was different, there was a small boy in a grey sweater sitting down beside the feed trough looking at the ducks. (That was my first impression). The small boy stood up and turned into a big long-legged Lynx. She looked straight at me with her big yellow eyes. In two bounds she was on the wooden fence that runs from the corrals to the lake. Then she turned around and looked at me again. With a sort of silent snarl, she disappeared into the water willows. I saw right away that it was a lactating female. She must have caught two or three of our ducks every day when they came to shore to feed, preen their feathers and sleep. There must have been lynx kittens in the bush nearby.

We rounded up our remaining twenty-two ducks and took them to a neighbour to raise. In the fall, they were as big as small geese. We gave a lot of them away and had roasted duck quite often that winter.

That same fall on our nearest neighbour's farm, a tame goose was killed. It was dragged into the bush, fed on and covered with snow and dried leaves. The neighbour set a trap and the next day there was a small Lynx in it. That could have been one of our Lynx kittens.

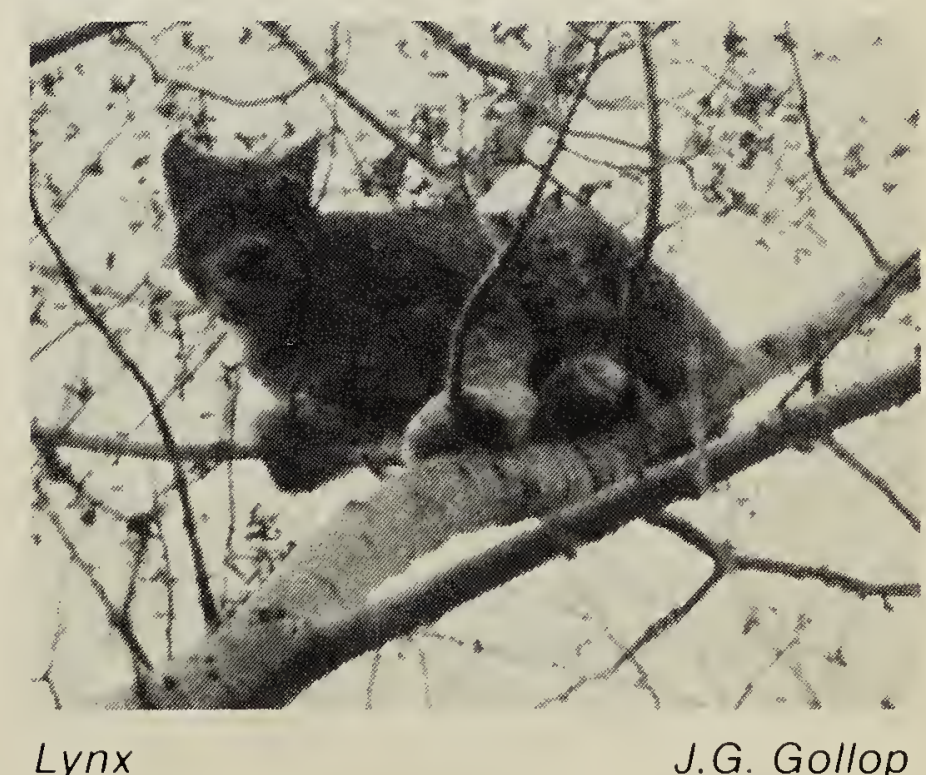

Lynx

J.G. Gollop 